\section{Plant genes now fashionable}

\section{Washington}

THE US Department of Agriculture (USDA), frequently criticized for its neglect of plant molecular biology, is now preparing to open a showcase institute with this theme at Albany, near San Francisco, California. The new Plant Gene Expression Center could herald a growth of interest from other government agencies.

At the outset, the new centre, under the aegis of USDA's Agricultural Research Service (ARS), will work on the transformation and regeneration of monocotyledons, the use of transposons to 'tag' and identify genes, molecular mechanisms of hormone action and environmental reg-

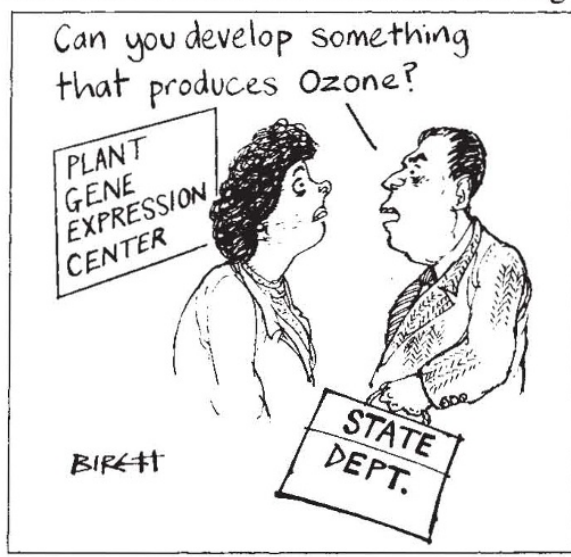

ulation of gene expression. USDA's annual support will be about $\$ 6$ million, but extra funds will be sought from other sources.

The scientific director will be Peter Quail, now at the University of Wiscon$\sin$. The centre will eventually house 10 research groups, some of whose leaders will also be professors at the nearby Berkeley campus of the University of Califor- nia. Quail says the Berkeley link will be important; staff will be employees of the university, not civil servants, and visiting scientists will play a vital role. He hopes the centre will develop techniques for manipulating plant genes coding for informational molecules that will have longterm applications in crop improvement.

But while USDA is planning its own modest expansion of basic plant biology, the White House's Office of Science and Technology Policy is pushing for a more far-reaching increase in federal support. The view there (shared elsewhere) is that plant science has been eclipsed by the popularity of biomedicine, and urgent action is needed to redress the balance.

Indeed, the Office of Management and Budget hopes that there will be funds in the 1988 federal budget for an interagency initiative in basic plant biology This proposal has been made by the Departments of Agriculture and Energy and the National Science Foundation and would support several new 'interdisciplinary research groups' in plant biology at universities, concentrating in five areas:

- microbial ecology and genetics in the rhizosphere

- chemistry of complex plant carbohydrates

- molecular biology and genetics of plant cells

- modelling of agro-ecosystems

- information technology.

Part of the impetus for the new initiative is the need to develop a 'predictive ecology' to help resolve the regulatory paralysis over environmental releases of genetically modified organisms. Whether those who hold the purse strings will support a major expansion remains to be seen.

\title{
Grassroots unrest in plant biology
}

\section{Washington}

Despite the creation of the new Plant Gene Expression Center, seen by many as a belated attempt by (USDA) to jump on the plant biotechnology bandwagon, many academics believe research in basic plant biology has been seriously neglected.

The figures are telling; ARS's total budget will be $\$ 498$ million this year, but that is all in-house and includes the cost of running laboratories. At least one-half is applied research such as plant breeding.

The Cooperative State Research Service, the USDA research arm which, jointly with state governments, supports the state experimental research stations, has a budget of $\$ 300$ million, but only $\$ 40$ million goes as competitive grants open to the university community. On one estimate, total federal support for innovative basic plant science open to competitive proposals from academics, including programmes of the Departments of Agriculture and Energy and the National Science Foundation, is only $\$ 110$ million, compared with over $\$ 3,000$ million spent on basic research by the National Institutes of Health in $\mathbf{1 9 8 6 .}$

ARS does support many small projects that use modern molecular biology techniques, but critics, such as Roger Salquis, president of Calgene Inc., and Stanford's Virginia Walbot agree it could have made better use of its opportunities. And the minuscule competitive grants programme, though increased in size in recent years. is not popular with academics; fewer than 10 per cent of proposals succeed, while grants (including overhead) vary between $\$ 50,000$ and $\$ 80,000$ in amount and last for only two years.
Some academics are sceptical about the plan, saying that researchers can collaborate when they need to as things are and that the plan may simply be a way of dressing up a case for more money. Virginia Walbot of Stanford University believes

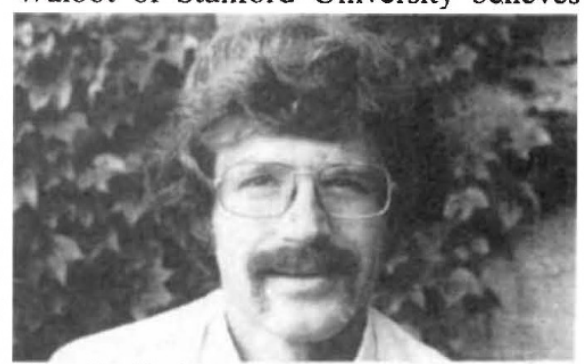

Peter Quail: aiming at better crops despite agricultural surpluses.

that universities will find it hard to assemble true interdisciplinary groups without the promise of long-term support, which may be hard to get.

Others point out that the director of the Office of Science and Technology Policy, William Graham, whose support would be vital, has a background in defence, and may not be enthusiastic about biological research.

On a political level, the problems of US farmers are seen as stemming more from surpluses than from shortages, and biological research is seen - rightly or wrongly - principally as a way to make the surpluses bigger. Tim Beardsley

\section{FRG-Soviet agreement}

\section{German deal put on ice}

\section{Hamburg}

THE proposed agreement on research collaboration between West Germany and the Soviet Union seems to have been one of the first victims of the ill-feeling generated by Chancellor Helmut Kohl's controversial reference last month to $\mathrm{Mr}$ Mikhail Gorbachev, the general secretary of the Soviet Communist Party.

In an interview with the US news magazine Newsweek, Kohl had described Gorbachev as an "expert in public relations" and had likened him to Hitler's minister of propaganda, Josef Goebbels. Now Moscow has cancelled a visit during which $\mathrm{Dr}$ Heinz Riesenhüber, minister of research and technology in the federal government, was to have signed an agreement on the peaceful uses of nuclear energy and other matters reached only in July this year (Nature 322, 488; 1986) after a decade of intermittent negotiation.

As things are, there is an exchange agreement between the Deutsche Forschung Gemeinschaft (DFG) and the Soviet Academy of Sciences but no agreement on scientific collaboration between the West German and Soviet governments.

Jürgen Neffe 